\title{
REDUCING THE ROLE CONFLICT OF WORKING WOMAN: BETWEEN WORK AND FAMILY CENTRALITY
}

\author{
Desti Ranihusna, $\bowtie$ Nury Ariani Wulansari ${ }^{\bowtie}$ \\ Faculty of Ecomonics, Universitas Negeri Semarang, Semarang, Indonesia
}

\begin{tabular}{l} 
Info Artikel \\
\hline Sejarah Artikel: \\
Diterima Juni 2015 \\
Disetujui Juli 2015 \\
Diterbitkan September 2015 \\
\\
\hline Keywords: \\
Pay Satisfaction (PS); \\
Work-Family Conflict (WFC); \\
Family-Work Conflict (FWC); \\
Job Satisfaction (JS); \\
Work Family Centrality \\
\end{tabular}

\begin{abstract}
The aim of this study is to test the direct impact on pay satisfaction in WFC and examines direct effect of WFC and FWC for work satisfaction. It also examines the impact of the moderating variable of work-family centrality moderating variable) from the relation of WFC and FWC in work satisfaction (a case study of married female lecturers in UNNES). This research was done because there were differences between results of WFC and FWC to JS and recommendation to add moderating variable and PS to WFC. It used SPSS to examine hypothesis with CFA, to test validity, classical assumption testing and test was also used. The moderating variable was tested by the value of absolute deviation. The data in this research is primary data in the form of questionnaire and interview. The result shows that there are high impacts between PS and WFC. There is no effect between WFC and FWC to JS. Supporting moderating variable is Work Centrality. Although, they prioritize their family, female lecturers are still trying to work professionally.
\end{abstract}

\section{MEREDUKSI KONFLIK PERAN WANITA BEKERJA MELALUI MODERASI WORK FAMILY CENTRALITY}

\begin{abstract}
Abstrak
Penelitian ini bertujuan untuk menemukan pengaruh langsung dari pay satisfaction pada WFC dan menguji pengaruh langsung WFC dan FWC pada kepuasan kerja, serta pengaruh variabel moderator sentralitas pekerjaan-keluarga dari hubungan WFC dan FWC pada kepuasan kerja tersebut (studi kasus pada dosen wanita yang telah menikah di UNNES). Penelitian ini dilakukan karena ada perbedaan hasil penelitian tentang WFC dan FWC terhadap JS dan rekomendasi untuk menambahkan variabel moderasi serta PS pada WFC. Penelitian ini menggunakan SPSS untuk menguji hipotesis dengan CFA untuk Uji validitas, juga menggunakan uji asumsi klasik dan uji t. Variabel moderasi diuji dengan nilai selisih mutlak. Data yang digunakan dalam penelitian ini adalah data primer berupa kuesioner dan interview. Hasilnya menunjukkan bahwa ada pengaruh yang kuat antara PS dengan WFC. Tidak ada pengaruh WFC dan FWC terhadap JS. Variabel moderasi yang mendukung adalah Work Centrality. Meski mengutamakan keluarga, dosen wanita tetap berupaya bekerja secara profesional.
\end{abstract}

JEL Classification: M0, M5, M54

${ }^{凶}$ Alamat Korespondensi

Fakultas Ekonomi, Universitas Negeri Semarang

Jl. Taman Siswa, Sekaran, Gunungpati,Semarang

E-mail: d.ranihusna@gmail.com; nuryarianiwulansari@gmail.com 
Desty Ranihusna \& Nury Ariani Wulansari / Reducing The Role Conflict of...

\section{INTRODUCTION}

Nowadays, women emancipation is growing fast in Indonesia. Their role is not only in their familybutalso in the workplace. Today's workplace condition has got much female's contribution, both in the level of technic or strategic policy. Female emancipation is getting improve in the workplace because women existence is ackowledge through high performance.

According to Maslow theory, there are some reasons whay woman works. They are family needs and self-actualization. Furthur, by having many activities a woman will have more confidence both in family and in her society. In addition, another reason whay a woman works is because of their social status as a single parent.

Workplace and family are two important things for someone life (Mian et al., 2012). A woman that has those condition is called as working woman. Although she has a job, work and family become two things that can not be separated from her attention. The attention can be time, energy, and thougth about work or family roles (Carr et al., 2008). Both of these should be able in harmony to support working mother's life. Moreover, her performance will increase so that, it creates job satisfaction.

The requirements for being a working woman is not easy, as she should be a wife, mother, and employee at the same time. More, sometimes it has some contradictions and creates conflicts or problems. According to Netemeyer et al. (1996), there are two types of the dual role; Work-Family Conflict (WFC) and Family-Work Conflict (FWC). Work-Family Conflict (WFC) is defined by Netemeyer et all. (1996) as a form of conflict in roles, including job and family demand, time and job strain. It interfere her role in the family. For instance, the organization as a workplace requires working mother to have overtime work in holiday or lateness for going back home, so she can not fulfill her role in the family.
Family-Work Conflict (FWC) is a form of conflict in roles, including time and family strain from a family that disturbs in doing responsibility in the workplace (Netemeyer et al., 1996). For example is when their children get sick, she should choose between two roles, that is as a mother or employee at the same time. The condition will make the family conflict emerge in the workplace. If she can not cope with this condition, her work life will be interrupted. As a result, the performance will reduce. The previous researches have more studies on WFC rather than FWC. Since WFC has a more serious impacts on the employee's life and the company performance (Bagger \& Andre, 2012). Therefore, WFC and FWC need to be studied because both of them have an impact on workoutcomes, for example reducing job satisfaction, organization commitment and increasing turnover intention (Alsam et al., 2013; Li et al., 2013).

There are different results of researches about the effect of FWC and job satisfaction. Rathi and Barath (2013) found that FWC has a negative impact on job satisfaction. Whereas Namasivayam (2004) stated that FWC has a positive relationship to job satisfaction. It means that if an employee gets FWC, job satisfaction will increase. Furthermore, employees conflicts is also influenced by pay satisfaction level. It supports Ryan's (2009) findings. He argued that pay satisfaction level has a negative impact on the low level of WFC.

On the other hand, Mian et al. (2012) suggested to add the variable of Work-Family Centrality in the model testing of WFC and FWC. Carr et al. (2008), declared the negative impact of WFC on job satisfaction will be weakened by Work Centrality. WorkFamily Centrality is a moderating variable that can strengthen or weaken the relationship between WFC and FWC to job satisfaction. If the employees consider that the personal life is more important than the work life, the negative relationship between WFC and job satisfaction is weakened. It occurs if the employees prioritize more on working 
rather than family (Work-Cetrality). On the opposite, if the employees emphasize more on family than work, the influence of WFC on job satisfaction will be weakened (FamilyCentrality).

This study took female lecturers as sample. They have to fulfill the obligatory task, namely Tri Dharma Perguruan Tinggi. It covers teaching and learning, conducting a research and having community services. Then, she will spend much time on her activities, so she should balance her roles in family and work. As a result of this condition, role conflict and job dissatisfaction will rise.

Some previous study about the influence of pay satisfaction towards WFC have been the basis for this hypothesis. Ryan (2009) said that there are significant impacts between those both variables. Lum et al. (1998) said that pay satisfaction means someone will be satisfied if her salary perception is suitable with his expectation. As a result, her efforts, salary, and rewards are balanced, or in other words, she has got pay satisfaction. Pay satisfaction is measured by having four dimensions of PSQ (Pay satisfaction questionnaire), with indicators as follows: Pay level, Benefits, Pay raise, Pay structure and administration. If someone has got satisfied salary, so she will decrease the conflict between her work and family. Based on those statements, a hypothesis can be constructed as follows:

$\mathrm{H} 1$ : pay satisfaction affect to work family conflict.

On the other hand, if she faces the conflict of work and family, so her job satisfaction will decline. Namasivayam (2004) found a negative effect on the relationship between WFC and employee job satisfaction. It is similar to the research of the Rathi and Barath (2013) and Carr et al. (2008). Based on above explanation, a hypothesis can be constructed as follows:

$\mathrm{H} 2$ : work family conflict has negative effect to the job satisfaction
Based on Bagger and Andrew (2012) FWC is a family conflict that interferes the responsibility between family and work. Karimi et al. (2012) also investigated the relationship between Family-Work Conflict (FWC) and the job satisfaction. There is negative significant relationship between FWC and job satisfaction (Bruck, 2002; Anafarta, 2011; Rathi \& Barath, 2013; Karimi, 2012; Afzal, 2014). On the other hand, there is inconsistency research result that WFC and FWC do not have a significant relationship to job satisfaction (Belendez, 2006), whereas the impact of moderating variable can be caused by family centrality or work centrality. Based on above explanation, a hypothesis can be constructed as follows:

H3: family work conflict has negative effect to the job satisfaction.

Work-Family Centrality is an individual value. Someone with his individual values is the one who prioritizes work or family in his personal life (Carlson \& Kacmar, 2000). The priority of people to the value importance between the role of their job and family give the conflict effect. The conflict will influence job satisfaction significantly.

When Family-Centrality is low, the effect of WFC to job satisfaction is moderated by Work-Centrality. It is similar to the investigation of Carr et al. (2008), which claimd that WorkFamily Centrality weaken the effect of WFC in job satisfaction. In another hand, when FamilyCentrality is high, Work-Centrality is not moderated, so the family centrality is omitted by work centrality. It is as the same as Bagger and Andrew's study (2012). They stated that the negative effect of FWC to the job satisfaction is weakened by work-family centrality. Based on that statement, the development of hypothesis can be constructed as follows:

H4a: the effect between Work-Family Conflict and job satisfaction is reduced by high work centrality.

H4b: the effect between Family-Work Conflict and job satisfaction is reduced by high family centrality. 
Desty Ranihusna \& Nury Ariani Wulansari / Reducing The Role Conflict of...

\section{METHOD}

Proportional random sampling was adopted for data collection. A self-administered questionnaire was distributed to 200 married female lecturer in Universitas Negeri Semarang (UNNES). The number of valid response rate of $72 \%$. This response rate is considered to be within the accepted limits. The questionnaire included a demographic variables, such as gender and age. The age of respondents varied between 25 and 56 years. The sample of this research is 144 married female lecturers in Universitas Negeri Semarang (UNNES). Proportional random sampling was used as a method to collect the sample. The Sample collection can be seen from this following Table 1.

Pay satisfaction was measured by using 18-item scale of PSQ (Pay Satisfaction Questionnaire).An exampleitem is "whether the salary is appropriate to my efforts." The scale's reliability was 0,79 . Work-Family Conflict was measured by using five items from Netemeyer et al. (1996) scale. An example item is "my job demand as a lecturer interferes my family and social life." The scale's reliability was 0,89 . Family-Work Conflict was measured by using five items from Netemeyer et al. (1996) scale. An example item is "sometimes I must ignore my job, so I can fulfill my role in family.” The scale's reliability was 0,88 . Work-Family Centrality was measured by using five items from Carlson dan Kacmar (2000) scale. An example item is "in my opinion, the personal goals of someone should prioritize more on work than family." Job satisfaction was measured by using eigth items from Spector (1985) scale. An example item is "I like work condition, including work hours, co-workers, subjects, etc." The scale's reliability was 0,83 . All items were rated on five points of Likert scale ( $1=$ completely disagree, $5=$ completely agree)

Data can be gained by implementing some methods, such as survey, observation, and documentation. Validity testing is done by using Confirmatory Factor Analysis (CFA). The first step was having KMO and Bartlett's Test. KMO and Barlett's Test value should $>0,50$ so it can be calculated by factor analysis. The method of analysis is descriptive or statistical descriptive analysis. To know that work-family centrality is moderating variable or not, moderation testing was done with absolute deviation testing, with moderating criteria as follows:

If value of sig is $<$ than 0.05 , it is included as moderating variable

If value of sig is > than 0.05 , it is not included as moderating variable

From Table 2, it can be concluded that value of KMO and Bartlett's Test reached the expected criteria. Therefore, factor analysis as the next step can be done. There are 4 invalid items, so those indicators are not included in research questions. The result of reliability instrument shows that the Cronbach Alpha is > 0,70 .

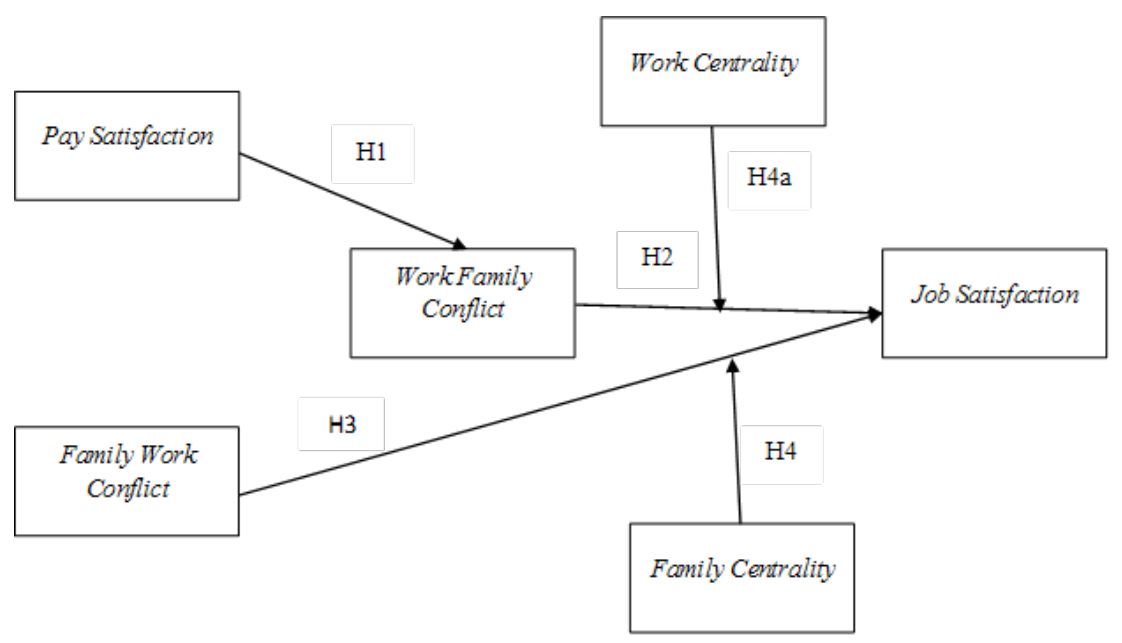

Figure 1. Mind Map 


\section{RESULTS AND DISCUSSIONS}

Descriptive analysis of each variable can be explained as follows. From the result of descriptive analysis of pay satisfaction, it can be demonstrated that indicator of salary level, benefits, salary increase, salary administration is included the as a high category. Therefore, it can be inferred that pay satisfaction of UNNES female lecturers is high.

The indicators of WFC are the demand of job that disturbs family, job that reduces selfinvolvement in the family, job that interferes family willingness, job that interrupts family's activity, conflict between job commitment and family responsibility. The above indicators are categorized low (45\%). Therefore, it can be said that conflict of work-family faced by female lecturers in Unnes is low.
The indicators of FWC are demand of family that disturbs job; work ignorance, family that disturbs job willingness, family that disturbs job responsibility, family activities that interferes coworker relationship is categorized low. Percentage of work-family conflict variable is $45 \%$; it is included as low category.

The indicators of Work-Family Centrality are the focus of one's life goal is on the job, the most important things is derived from work, prioritizing work, and the existence of job is the most important thing, her life satisfaction gained from her work. The result of descriptive analysis shows that percentage of work-family centrality variable is $45 \%$, it is categorized as a low category. It shows that female lecturer has more family centrality rather than work centrality. In other words, female lecturer prioritizes family comparing to the job.

Table 1 Proportional random sampling

\begin{tabular}{clccc}
\hline No & Faculty & Population & Proportion & Total Respondents \\
\hline 1 & FIP & 43 & $43 / 225 \times 144$ & 27 \\
2 & FBS & 40 & $40 / 225 \times 144$ & 26 \\
3 & FIS & 10 & $10 / 225 \times 144$ & 6 \\
4 & FMIPA & 54 & $54 / 224 \times 144$ & 34 \\
5 & FT & 29 & $29 / 225 \times 144$ & 19 \\
6 & FIK & 17 & $17 / 225 \times 144$ & 11 \\
7 & FE & 25 & $25 / 225 \times 144$ & 16 \\
8 & FH & 7 & $7 / 225 \times 144$ & 5 \\
\hline & Jumlah & 225 & & 144 \\
\hline
\end{tabular}

Sources: data processed (2015)

Table 2. Value of KMO and Bartlett's Test

\begin{tabular}{llcc}
\hline No & Variable & Value of KMO & Bartlett's Test \\
\cline { 1 - 2 } Expected value & $\mathbf{> 0 , 5}$ & $<\mathbf{0 , 5}$ \\
\hline 1 & Pay Satisfaction & 0,708 & 0,000 \\
2 & WFC & 0,866 & 0,000 \\
3 & FWC & 0,856 & 0,000 \\
4 & Work-family centrality & 0,814 & 0,000 \\
\hline
\end{tabular}

Source: data processed 2015 
Desty Ranihusna \& Nury Ariani Wulansari / Reducing The Role Conflict of...

Table 3. Factor Analysis

\begin{tabular}{clcl}
\hline No & Indicator & $\begin{array}{c}\text { Loading Factor } \\
\text { Expected Value }\end{array}$ & Notes \\
\hline 1 & X1.1 & 0,807 & Valid \\
2 & X1.2 & 0,832 & Valid \\
3 & X1.3 & 0,524 & Valid \\
4 & X1.4 & 0,639 & Valid \\
5 & X2.1 & 0,766 & Valid \\
6 & X2.2 & 0,848 & Valid \\
7 & X2.3 & 0,812 & Valid \\
8 & X2.4 & 0,736 & Valid \\
9 & X2.5 & 0,784 & Valid \\
10 & X3.1 & 0,773 & Valid \\
11 & X3.2 & 0,680 & Valid \\
12 & X3.3 & 0,738 & Valid \\
13 & X3.4 & 0,772 & Valid \\
14 & X3.5 & 0,773 & Valid \\
15 & X4.1 & 0,836 & Valid \\
16 & X4.2 & 0,788 & Valid \\
17 & X4.3 & 0,713 & Valid \\
18 & X4.4 & 0,828 & Valid \\
19 & X4.5 & 0,828 & Valid \\
20 & Y1 & 0,889 & Valid \\
21 & Y2 & Y3 & Valid \\
23 & Y4 & 0,892 & Valid \\
24 & Y5 & 0,698 & Not valid \\
25 & Y6 & 0,403 & Not valid \\
26 & Y7 & 0,366 & Valid \\
27 & Y8 & 0,518 & Not valid \\
\hline
\end{tabular}

Source: data processed (2015)

There are 4 indicators of job satisfaction variable; they are enough salary, appropriate salary, appreciation, and holiday. Percentage of job satisfaction is $75 \%$; it is categorized as a high category. Therefore, it can be said that job satisfaction of female lecturers in Universitas Negeri Semarang is high.

There are three assumptions that should be done to certain regression model; they are normality test, multicollinearity test, and heteroscedasticity test.
Based on Table 6, the value of sig is 0.639 , because $63.9 \% \geq 5 \%$, so Ho is supported. It means, variable of job satisfaction has normal distribution.

From Table 7, it can be seen that independent variable has value of tolerance $>0.1$ and value of VIF < 10 . Hence, it can be concluded that there is multicollinearity among independent variable in this regression model. To test heteroscedasticity, it can be done by observing scatterplot graph with spreading 
Table 4. Factor Analysis 2

\begin{tabular}{|c|c|c|c|}
\hline No & Indicators & \multirow{2}{*}{$\begin{array}{c}\text { Loading Factors } \\
>0,5\end{array}$} & \multirow[t]{2}{*}{ Notes } \\
\hline \multicolumn{2}{|c|}{ Expected value } & & \\
\hline 1 & $\mathrm{X} 1.1$ & 0,865 & Valid \\
\hline 2 & $\mathrm{X} 1.2$ & 0,870 & Valid \\
\hline 3 & $\mathrm{X} 1.3$ & 0,510 & Valid \\
\hline 4 & X1.4 & 0,642 & Valid \\
\hline 5 & $\mathrm{X} 2.1$ & 0,769 & Valid \\
\hline 6 & $\mathrm{X} 2.2$ & 0,846 & Valid \\
\hline 7 & $\mathrm{X} 2.3$ & 0,810 & Valid \\
\hline 8 & $\mathrm{X} 2.4$ & 0,743 & Valid \\
\hline 9 & $\mathrm{X} 2.5$ & 0,791 & Valid \\
\hline 10 & X3.1 & 0,777 & Valid \\
\hline 11 & X3.2 & 0,679 & Valid \\
\hline 12 & X3.3 & 0,747 & Valid \\
\hline 13 & X3.4 & 0,780 & Valid \\
\hline 14 & $\mathrm{X} 3.5$ & 0,736 & Valid \\
\hline 15 & $\mathrm{X} 4.1$ & 0,835 & Valid \\
\hline 16 & $\mathrm{X} 4.2$ & 0,791 & Valid \\
\hline 17 & $\mathrm{X} 4.3$ & 0,737 & Valid \\
\hline 18 & $\mathrm{X} 4.4$ & 0,819 & Valid \\
\hline 19 & $\mathrm{X} 4.5$ & 0,821 & Valid \\
\hline 20 & $\mathrm{Y} 1$ & 0,734 & Valid \\
\hline 21 & Y2 & 0,759 & Valid \\
\hline 22 & Y3 & 0,667 & Valid \\
\hline 23 & Y6 & 0,715 & Valid \\
\hline
\end{tabular}

Source: data processed (2015)

Table 5. Reality Testing

\begin{tabular}{clccl}
\hline No & \multicolumn{1}{c}{ Variable } & $\begin{array}{c}\text { Cronbach } \\
\text { Alpha }\end{array}$ & Criteria & Notes \\
\hline 1 & Pay satisfaction $(\mathrm{X} 1)$ & 0.792 & 0.70 & Reliable \\
2 & WFC (X2) & 0.895 & 0.70 & Reliable \\
3 & FWC (X3) & 0.882 & 0.70 & Reliable \\
4 & Work-family centrality (X4) & 0.872 & 0.70 & Reliable \\
5 & Job Satisfaction (Y) & 0.834 & 0.70 & Reliable \\
\hline
\end{tabular}

Source: data processed (2015) 
Desty Ranihusna \& Nury Ariani Wulansari / Reducing The Role Conflict of...

point pattern above $\mathrm{Y}$ and under $\mathrm{Y}$. The following is the result of plot graph using SPSS 19. From scatterplot graph, it can be seen that points are spreading randomly, both above some zero in Y. It can be concluded that there is no heteroscedasticity in this regression model.

Hypothesis testing was used to recognize direct impact on pay satisfaction to WFC and FWC, and then it was used to test the direct effect of WFC to job satisfaction and FWC to job satisfaction, and test moderating variable of work-family centrality.

Table 8 shows the significant impact, with value of 0,011 with level of significance is $0,05(5 \%)$. The result shows significant value gained is smaller than $0,05(0,011<0,05)$, so in partial, the result is that there is the impact on pay satisfaction and work-family conflict. Therefore, the $\mathrm{H} 1$ is supported.

Table 9 shows insignificant impact on value of 0,109 with the level of significance is $0,05(5 \%)$. The result shows significant value gained is greater than $0,05(0,011<0,05)$, so in partial, the result is that there is no impact of work-family conflict to job satisfaction. Therefore, the $\mathrm{H} 2$ is supported. Table 10 shows insignificant impact with value of 0,084 with level of significance is $0,05(5 \%)$. The result shows significant value is greater than 0,05 $(0,0084<0,05)$, so in partial, the result is that there is no impact of family-work conflict to job satisfaction. Therefore, $\mathrm{H} 3$ is supported.

Table 11 ilustrates a significant impact of work-family conflict, job centrality to job satisfaction, with a value of 0.028 , with level of significance of $0,05(5 \%)$. The result shows significant value is smaller than 0,05 $(0,028<0,05)$, so variable of job centrality is moderator variable in this research. Therefore, 4a hypothesis is supported.

The Table depicts the insignificant impact of family-work conflict, job centrality to job satisfaction, with a value of 0.023 , with level of significance of $0,05(5 \%)$ with a value of 0,084 with the level of significance of 0,05 (5\%). The result shows significant value is greater than 0,05 $(0,0223>0,05)$, so variable of job centrality is a moderator variable. Therefore, $4 \mathrm{~b}$ hypothesis is supported.

The result of analysis regression of pay satisfaction and WFC shows regression (see Table 6) with regression coefficients is $\mathrm{Y} 1=$ $16.634-0.348 \mathrm{X} 1+\mathrm{e} 1$. Thus, it can be said that if pay satisfaction is high, it will lower variable of WFC.

Table 6. Normality Test

One-Sample Kolmogorov-Smirnov Test

Unstandardized Residual

$\mathrm{N}$

Normal Parameters $\mathrm{s}^{\mathrm{a}, \mathrm{b}}$

Most Extreme Differences

Kolmogorov-Smirnov Z

Asymp. Sig. (2-tailed)
Mean

, 0000000

Std. Deviation

3,42626534

Absolute

,062

Positive

,047

Negative

a. Test distribution is Normal.

b. Calculated from data.

Source: data processed (2015) 
Table 7. Table of Muticollinearity Test

Coefficients $^{\mathrm{a}}$

\begin{tabular}{|c|c|c|c|c|c|c|c|c|}
\hline \multirow{2}{*}{\multicolumn{2}{|c|}{$\begin{array}{l}\text { Model } \\
\text { B } \\
\end{array}$}} & \multicolumn{2}{|c|}{$\begin{array}{c}\text { Unstandardized } \\
\text { Coefficients }\end{array}$} & \multirow[t]{2}{*}{$\begin{array}{c}\text { Standardized } \\
\text { Coefficients }\end{array}$} & \multirow[b]{2}{*}{$\mathbf{T}$} & \multirow{2}{*}{$\begin{array}{l}\text { Sig. } \\
\text { Toler- } \\
\text { ance }\end{array}$} & \multicolumn{2}{|c|}{$\begin{array}{l}\text { Collinearity } \\
\text { Statistics }\end{array}$} \\
\hline & & $\begin{array}{l}\text { Std. Er- } \\
\text { ror }\end{array}$ & Beta & & & & \multicolumn{2}{|l|}{ VIF } \\
\hline 1 & $\begin{array}{l}\text { (Con- } \\
\text { stant) }\end{array}$ & 6,592 & 1,404 & & 4,695 & ,000 & & \\
\hline & $\mathrm{X} 1$ & 581, & 071 & 574 & 8,144 & 000, & 953, & 1,049 \\
\hline & $\mathrm{X} 2$ & 044 & 066 & 071 & 664, & 508, & 413, & 2,424 \\
\hline & $\mathrm{X} 3$ &,- 065 & 071 & -095,- & -,909 & 365, & 432 & 2,315 \\
\hline & $\mathrm{X} 4$ &,- 030 & 049, & -,044 &,- 620 & 536, & 922 & 1,084 \\
\hline
\end{tabular}

a. Dependent Variable: $\mathrm{Y}$

Source: data processed (2015)

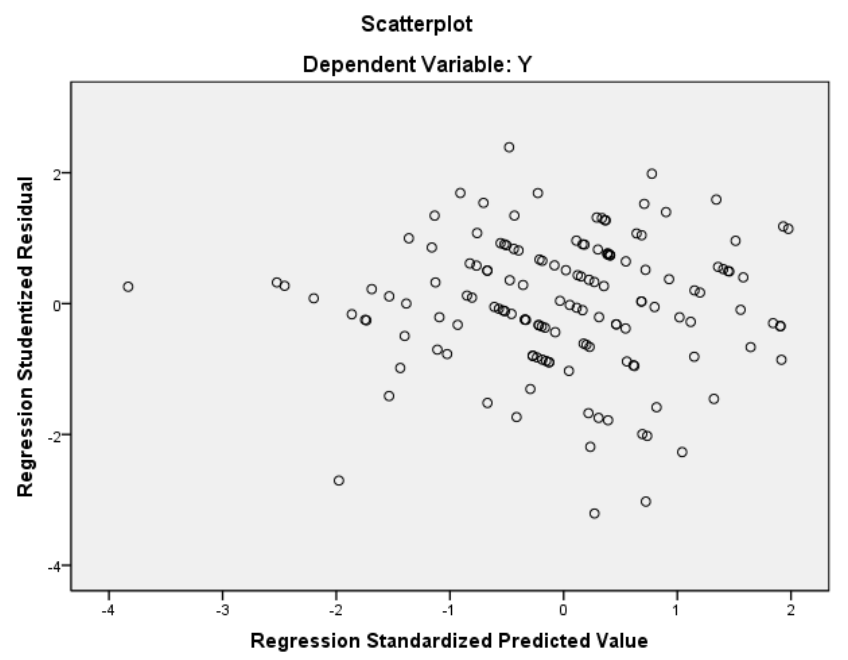

Figure 2. Heteroscedasticity Test with Scatterplot

The result of regression analysis of WFC and job satisfaction shows that regression coefficient is $\mathrm{Y} 2=15.893-0.082 \mathrm{X} 2+\mathrm{e} 2$. Thus, it can be said that high of WFC will decrease job satisfaction.

The result of regression analysis of FWC and job satisfaction shows that regression coefficient is $\mathrm{Y} 2=15.893-0.082 \mathrm{X} 2+\mathrm{e} 2$. Thus, it can be said that high of FWC will increase job satisfaction.

Analysis of moderating regression with analysis absolute deviation testing using SPSS 19 program shows that regression coefficient is $\mathrm{Y}=15.253+0.001 \mathrm{X} 2-0.328 \mathrm{X} 3-0.202 \mathrm{X} 4$ $-0.199|\mathrm{X} 2-\mathrm{X} 4|-0.115|\mathrm{X} 3-\mathrm{X} 4|$. Thus, it can be said that variable of Work-Family Conflict and variable of Family-Work Conflict is negative, but Work-Family Centrality is positive. It will increase job satisfaction.

The result of hypothesis testing shows that pay satisfaction has an impact to WFC. It is supported by Ryan (2009). If a female lecturer gets high pay satisfaction, WFC gotten will be low. They will feel working on campus is easy and comfortable because it is paid by salary or benefits as its sacrifice. It is expected 
Desty Ranihusna \& Nury Ariani Wulansari / Reducing The Role Conflict of...

Table 8. Hypothesis test with Variable of Pay Satisfaction and WFC

\section{Coefficients $^{\mathrm{a}}$}

\begin{tabular}{llcccccc}
\hline \multirow{2}{*}{$\begin{array}{l}\text { Model } \\
\text { B }\end{array}$} & & \multicolumn{2}{c}{$\begin{array}{c}\text { Unstandardized } \\
\text { Coefficients }\end{array}$} & \multicolumn{2}{c}{$\begin{array}{c}\text { Standardized } \\
\text { Coefficients }\end{array}$} & & \\
\cline { 2 - 4 } & & Std. Error & Beta & & T & Sig. \\
\hline 1 & (Constant) & 16,634 & 2,106 & & 7,899 &, 000 \\
& X1 &,- 348 &, 135 &,- 211 & $-2,574$ &, 011 \\
\hline
\end{tabular}

a. Dependent Variable: $\mathrm{X} 2$

Source: data processed (2015)

Table 9. Hypothesis Test with Variable of WFC to Job Satisfaction

Coefficients $^{a}$

\begin{tabular}{llccccc}
\hline \multirow{2}{*}{$\begin{array}{l}\text { Model } \\
\text { B }\end{array}$} & \multicolumn{2}{c}{$\begin{array}{c}\text { Unstandardized } \\
\text { Coefficients }\end{array}$} & $\begin{array}{c}\text { Standardized } \\
\text { Coefficients }\end{array}$ & & \\
\cline { 2 - 4 } & & Std. Error & Beta & & T & Sig. \\
\hline 1 & (Constant) & 15,893 &, 610 & & 26,071 &, 000 \\
& X2 &,- 082 &, 051 &,- 134 & $-1,612$ &, 109 \\
\hline
\end{tabular}

a. Dependent Variable: $Y$

Source: data processed (2015)

Table 10. Hypothesis Test with Variable FWC to Job Satisfaction

Coefficients $^{\mathbf{a}}$

\begin{tabular}{llccccc}
\hline \multirow{2}{*}{$\begin{array}{l}\text { Model } \\
\text { B }\end{array}$} & & \multicolumn{2}{c}{$\begin{array}{c}\text { Unstandardized } \\
\text { Coefficients }\end{array}$} & $\begin{array}{c}\text { Standardized } \\
\text { Coefficients }\end{array}$ & & \\
\cline { 2 - 5 } & & Std. Error & Beta & & T & Sig. \\
\hline 1 & (Constant) & 16,046 &, 652 & & 24,613 &, 000 \\
& X3 &,- 099 &, 057 &,- 145 & $-1,742$ &, 084 \\
\hline
\end{tabular}

a. Dependent Variable: $Y$

Source: data processed (2015)

that allocation of remuneration system is able to create task distribution and its benefit. Team work can be done conducively as the members in the team supports each other. The salary received is divided based on the task and responsibility. Academic atmosphere in the future is to work together and help each other in order to get same prosperity. It is able to increase satisfaction between job and benefits accepted.

The result of hypothesis testing shows that of work-family conflict has a negative impact to job satisfaction and it is not supported. The result is supported by research of Belendex et al. (2006). Namasivayam (2004), explained that FWC has positive relationship to job satisfaction. Conflict faced by female lecturers in Unnes is categorized as low because they can work professionally, manage the time and do their work as well as mother and wife. Therefore, they feel comfortable and happy with their works. Further, support from the whole family can minimize the conflicting role they feel so far. Family should be able to understand that being a lecturers she needs high self-actualization that requires a long period of learning and writing research. 
Table 11. Hypothesis Test and Moderation Analysis

Coefficients $^{\mathrm{a}}$

\begin{tabular}{llccccc}
\hline \multirow{2}{*}{$\begin{array}{l}\text { Model } \\
\text { B }\end{array}$} & & \multicolumn{2}{c}{$\begin{array}{l}\text { Unstandardized } \\
\text { Coefficients }\end{array}$} & $\begin{array}{c}\text { Standardized } \\
\text { Coefficients }\end{array}$ & & \\
\cline { 2 - 4 } & & Std. Error & Beta & & T & Sig. \\
\hline 1 & (Constant) & 15,253 &, 336 & & 45,442 &, 000 \\
& Zscore(X2) &, 001 &, 314 &, 000 &, 003 &, 998 \\
& Zscore(X3) &,- 328 &, 308 &,- 135 & $-1,067$ &, 288 \\
& Zscore(X4) &,- 202 &, 209 &,- 083 &,- 964 &, 337 \\
& ModerasiX2_X4 &,- 199 &, 089 &,- 240 & $-2,228$ &, 028 \\
& ModerasiX3_X4 &, 115 &, 094 &, 132 & 1,223 &, 223 \\
\hline
\end{tabular}

a. Dependent Variable: $Y$

Source: data processed (2015)

The result of hypothesis, Work-Family Conflict has a negative impact toward job satisfaction is not supported. This result is supported by Anafara (2010). He stated that FWC is not significant toward job satisfaction. Some collectivism based countries also have similar finding on their researches. Indonesia belongs to the collectivism country. For its society family becomes the main focus. They try to use proper time management so that quality time with family is not bothered as well as their work stuff.

They expect to perform better in the family as mother and wife. It is suggested for young women lecturers who have toddlers to spare their time driving and picking up their children that later on will make children happy. Surely at the same time, there is communication in between for children to share their school activities to their moms. They are accustomed to having dinner together and share their weekend for family activities such as watching television together, having vacation or simply eating out. Whereas the working stuff besides teaching is that they have more flexibility in writing research, finishing report and doing community service. This management can optimize their role at home without bothering their task at the campus.

The result of hypothesis shows that work centrality is proven to be weak toward family work conflict and job satisfaction. This result is in line with the research resulted by Carr et al. (2008) which testing the workers of Manufacture
Company with the result that work-family centrality weaken negative impact between work family conflict toward job satisfaction. Whereas from the test of other hypothesis shows that influenced hypothesis between work family conflicts toward job satisfaction is weakened when the centrality of family is not supported. This research is supported by Bagger and Andrew (2012) who stated that only one variable that moderate it, they are either work centrality or family centrality, not both.

Research result about job centrality shows that female lecturers view a family as a priority and it cannot be ignored. However, they can still work professionally. They feel happy to work as a lecturer by developing Tri Dharma Perguruan Tinggi. Furthermore, based on their opinion living among students is happiness. It also happens when they do research and community service as there are new experiences, interesting finding, and advanced networking. Female lecturer with flexible time and various-plentifultight activities tries to teach professionally, finishing jobs during breaks as a mother, taking care of children and fulfilling family needs in immerse before going to campus.

\section{CONCLUSION}

Results of the study show that there is high influence between pay satisfaction (PS) and WFC. However, there is not any 
Desty Ranihusna \& Nury Ariani Wulansari / Reducing The Role Conflict of...

relationship between WFC and FWC toward job satisfaction (JS). This finding supports the research of Anafar (2010). Indonesia belongs to the collective country which prioritizes family, but its society still tries to be professional in work. Women lecturer with various roles for instance as a mother, wife, and a professional worker are actually tough. Besides working professionally, support from the organization especially the leader.

Becoming a working mother is not easy because she should perform two roles at the same time. If they have already worked hard and professionally as a mother, wife, and lecturer, they should receive support from any parties. This research is possible to be studied in broader contexts related to the conflict condition in public or private universities as well as other institutes or professional worker such as doctors.

\section{REFERENCES}

Afzal, S \& Yasir, A .F. 2014. Impact of work family conflict/family work conflict on job satisfaction and life satisfaction: A case Study of a Publik Sector University Gujranwala Division Pakistan. International Journal of Multidisciplinary Science and Engineering. 5 (8).

Alsam, N dkk. 2013.The Impact of Work Family Conflict on Turnover Intentions: An Empirical Evidence from Pakistan. World Applied Sciences Journal. 24 (5): 628-633.

Anafarta, N. 2011.The Relationship between Work-Family Conflict and Job Satisfaction: A Structural Equation Modeling (SEM) Approach. International Journal of Business and Management. 6 (4).

Bagger, J \& Li, A. 2012. Being important matters: The impact of work and family centralities on the family-to-work conflict satisfaction relationship. Journal of Human Relations. 65: 473.

Belendez, M., Martin, L. M \& Topa, G. 2006. Job strain, work-family conflict and job satisfaction among employees in advertising agencies. 7th Conference of the European Academy of Occupational Health Psychology, Dublin 8-10 November 2006.

Bruck, C., Alen, T\& Spector, P. 2002.The Relation between Work-Family Conflict and Job
Satisfaction: A Finer-Grained Analysis. Journal of Vocational Behavior. 60: 336-353.

Carlson, D. S \& Michele, K. K. 2000. Work-Family Conflict in the Organization: Do Life Role Values make a Difference?. Journal of Management 2000.26 (5): 1031-1054.

Carr, Jon, C., Scott, L. B \& Brian, T. G. 2008. The Moderating Effect of Work Family Centrality on Work Family Conflict, Organizational Attitudes, and Turnover Behavior?. Journal of Management. 34: 244.

Greenhaus, J. H \& Beutell, N. J. 1985. Sources of conflict between work and family roles. Academy of Management Review. 10 (7): 76-88.

Karimi, Q. dkk. 2012. Consequence of Conflict between Work and Family among Iranian Female Teacher. Journal of Basic and Applied Scientific Research. 2 (2): 1869-1875.

Li, C. dkk. 2013. Cross-Domain Effect of WorkFamily Conflict on Organizational Commitment and Performance. Sosial Behavior and Personality. 41 (10): 16411654.

Lum, L., Kervin, J., Clark, K., Reid, K \& Sola, W. 1998. Explaining Nursing Turnover Intent : Job Satisfaction, Pay Satisfaction, or Organizational Commitment. Journal of Organizational Behavior. 19: 305-320.

Mian, Z., Rodger, W. F \& David, D. F. 2012. Workfamily conflict and individual consequence. Journal of Managerial Psychology. 27 (7): 696713.

Namasivayam, K. 2004. The relationship of workfamily conflicts and family-work conflict to job satisfaction. Journal of Hospitality $\omega$ Tourism Research. 28 (2): 242-250.

Netermeyer, R. G., James, S., Boles \& Robert, M. 1996. Development and Validation of WorkFamily Conflict and Family-Work Conflict Scales. Journal of Applied Psychology. 81 (4): 400-410.

Rathi \& Barath. 2013. Work-family conflict and job and family satisfaction Moder a t ing effect of social support among police personnel. Equality, Diversity and Inclusion: An International Journal. 32 (4): 438-454.

Robbins, S. P \& Timothy, A. J . 2008. Perilaku Organisasi (Edisi 12). Jakarta: Salemba Empat

Ryan, T. D. 2009. Relationship between Pay Satisfaction, Work-Family Conflict, and Coaching Turnover Intentions. Team Performance Manajemen. 15 (3): 128-140.

Sanusi, A. 2012. Metodologi Penelitian Bisnis. Jakarta: Salemba Empat. 